\title{
PARLIAMENT'S POWER TO REQUIRE THE PRODUCTION OF DOCUMENTS - A RECENT Victorian CASE
}

\section{GREg TAYLOR*}

In 2007, the Victorian government refused to produce a series of documents despite an order by the State's Legislative Council to do so, claiming that the Council's legal powers did not extend to making the order in question. The government cited some obscure alleged rules of law in support of their position which no government elsewhere in Australia has ever thought to rely on. In citing these rules, the Victorian government appears to have misunderstood an early edition of Erskine May. This article demonstrates that none of the alleged rules exists, and the government's refusal was wrong in law. Therefore is should not be regarded as setting a precedent for future cases.

\section{INTRODUCTION}

On 19 September 2007, the Victorian Legislative Council passed a motion calling for various reports and other papers produced by, or in connection with the work of, the Victorian Commission for Gambling Regulation ${ }^{1}$ and relating to the allocation of public lotteries licences. The motion passed on party lines by twenty-one votes to nineteen. ${ }^{2}$ The votes against were from the nineteen ALP members of the Council, while those in favour were from the Liberal Party, National Party, and Greens representatives and the sole representative of the Democratic Labor Party. The reports and papers were

\footnotetext{
* Associate Professor, Faculty of Law, Monash University; Visiting Professor, Osgoode Hall Law School, York University, Toronto. The author thanks Professor Jeffrey Goldsworthy, anonymous providers of information and the referee for this journal for their assistance and comments in the writing of this article. The usual caveat applies

${ }_{2}^{1}$ Established by the Gambling Regulation Act 2003 (Vic) s 10.1.1(1).

2 Victoria, Minutes of the Proceedings, Legislative Council, 19 September 2007, 186-7; Victoria, Parliamentary Debates, 19 September 2007, 2752-81.
} 
said to be required in aid of the inquiry into alleged irregularities and other matters being conducted by the Select Committee on Gaming Licensing. ${ }^{3}$

The government has since repeatedly advised the Council that it will not comply with the order, claiming executive privilege. ${ }^{4}$ Its basis for this claim may be found in a letter dated 21 June 2007 provided by the AttorneyGeneral for Victoria, Rob Hulls, to the Select Committee on Gaming Licensing, which had also issued summonses requiring the production of documents. $^{5}$ In his letter, Hulls A-G correctly states that the power of a House of the Parliament of Victoria to require the production of documents is to be found in section 19(1) of the Constitution Act 1975 (Vic), and concedes that this generally permits the Legislative Council to require the production of documents. The power may of course also be delegated to committees.

Section 19(1) equates the powers of each House of the Victorian Parliament to those of the House of Commons on 21 July $1855 .{ }^{6}$ However, Hulls A-G states in his letter that on this basis there are no fewer than three applicable exceptions that justify the non-production in this case:

- first, privilege. Executive privilege, as would be available in litigation, is said to have existed as an exception to the Houses' powers in 1855 because the House of Commons, according to Hulls A-G, at that time passed mere addresses seeking the voluntary production of documents from the Crown, ${ }^{7}$ rather than orders formally requiring their production; and this principle is also claimed to include Cabinet documents and to cover documents subject to

\footnotetext{
${ }^{3}$ The resolution establishing the Committee and providing for the terms of the inquiry is at Victoria, Minutes of the Proceedings, Legislative Council, 14 February 2007, 28-9.

${ }^{4}$ Victoria, Minutes of the Proceedings, Legislative Council, 9 October 2007, 197; 30 October 2007, 213ff; 20 November 2007, 239-40.

${ }^{5}$ Reproduced in Victoria, First Interim Report: Select Committee of the Legislative Council on Gaming Licensing, Parl Paper No 30 (2007) Appendix L.

${ }^{6}$ In The Constitution of Victoria (2006), 259, I stated that this date was chosen because it was the date on which the first Victorian Constitution received the Royal assent. This statement was based on fn (a) at 255 of vol II of the 1958 consolidation of Victorian statutes, which appears to have been adopted as correct by the drafter of the 1975 Act when the decision was taken to mention a date expressly in the statute. That footnote is, however, a few days out, as therefore is also my book on this point. The date of Royal assent was 16 July 1855, as appears from the reproduction of Victoria Constitution Act 1855 (Imp) in the Statutes at Large and at http://www.foundingdocs.gov.au/scan.asp?sID=758 (visited 9 April 2008).

7 The Victorian Commission for Gambling Regulation represents the Crown: Gambling Regulation Act 2003 s 10.1.2. Ministers are, of course, Ministers of the Crown: Constitution Act 1975 (Vic) s 50 (2). See further Interpretation of Legislation Act 1984 (Vic) s 46A(1).
} 
what, in the law of evidence, would be recognised as legal professional privilege;

- secondly, an alleged incapacity 'to call for documents relating to the affairs of private individuals or bodies, except where those individuals or bodies are receiving public funds or special privileges or performing some special function';

- finally, section 10.1.31(1) of the Gambling Regulation Act 2003 (Vic), which exempts certain persons, including the Commission, ${ }^{8}$ from the compulsory production or disclosure of documents produced under that Act to 'a court', which is defined in section 10.1.29(1) to include 'any tribunal, authority or person having power to require the production of documents or the answering of questions'.

These alleged exceptions are presented as propositions of law, not of Parliamentary practice or even constitutional convention, and it is the aim of this article to show that there are no such legal rules. I shall also refer to the emerging practice of bodies such as the Legislative Council of New South Wales in this field. However, given the nature of the arguments put forward by the Attorney-General, the recent adoption of those practices in New South Wales and their possible further evolution, my chief focus is on the extent of the strict legal powers of each House of the Victorian Parliament.

The consequence of the first and second points above, if they were valid objections, would be that the Council could not require the production of a large number of documents from the Crown, and it could not require them from private persons either except in the three cases mentioned in the second dot point above (receipt of public funds, etc). The Attorney-General also appears to be of the view that the executive is to be the judge of this question. At least, it is hard to see how the House could be the judge if it does not obtain the document and if the extent of its powers to require production is dependent upon a determination - necessarily made by someone else if its powers to obtain documents are truly to be limited - of whether a privilege exists. These facts alone might make us suspicious of the Attorney-General's view of the state of the law. The exception would come close to swallowing up the rule, and its applicability would, moreover, be decided upon by the body that is supposed to be the subject of supervision. While the government is to be congratulated for its research skills in unearthing these alleged restrictions from old textbooks, the exceptions do not, unfortunately for it,

\footnotetext{
${ }^{8}$ See the definition of 'regulated person' in s 10.1.29(1).
} 
exist. The statements by the Attorney-General are wrong in law and cannot be allowed to remain on the public record uncorrected.

In the dispute which is the subject of this note, the Legislative Council rightly refused to accept these alleged restrictions as an accurate statement of its powers. ${ }^{9}$ When it became clear that the government would not comply with the order for the production of documents, ${ }^{10}$ the Council adjudged the Leader of the Government (the Hon John Lenders, MLC, Treasurer), to whom its later demands had formally been addressed, guilty of a contempt. ${ }^{11}$ It ultimately suspended him from the Council for part of a sitting day as a mark of its censure. ${ }^{12}$ The Hon Mr Lenders was not in the chamber at the time at which his suspension took effect, ${ }^{13}$ so the sanction was purely symbolic.

Matters have rested there for the time being. At one stage, the present author heard informally of moves to have the question resolved by litigation. In its final report the Select Committee on Gaming Licensing noted that litigation was possibly the only way in which the question might be resolved and that its investigation had been hindered by the non-provision of information to it; as a result of this it was unable to reach a final conclusion on the important matters referred to it. ${ }^{14}$ But litigation to remove this obstacle requires a political will, and the will seems to have diminished markedly since the leadership of the Opposition in the Legislative Council changed at the start of 2008 and political priorities altered. ${ }^{15}$ Slightly earlier, a report by the Gambling and Lotteries Licence Review Panel, chaired by Ronald Merkel QC, was tabled on 11 October $2007,{ }^{16}$ and generally endorsed the licensing process. This also contributed to the reduction of political controversy in this area. While the political incentive to seek production of the documents through litigation appears to have dissipated in this case - the Select

\footnotetext{
${ }^{9}$ Victoria, Minutes of Proceedings, Legislative Council, 31 October 2007, 224.

${ }^{10}$ See above $\mathrm{n} 4$.

${ }^{11}$ Victoria, Minutes of Proceedings, Legislative Council, 21 November 2007, 255[7] (P R

Davis). It seems that this step has never been taken at federal level: Ian Harris (ed), House of Representatives Practice, $\left(5^{\text {th }}\right.$ ed, 2005) 662.

${ }^{12}$ Victoria, Minutes of Proceedings, Legislative Council, 22 November 2007, 260.

${ }^{13}$ David Rood, 'Treasurer Defiant after Upper House Suspension', The Age (Melbourne), 23 November 2007, 9.

${ }^{14}$ Victoria, Final Report: Select Committee of the Legislative Council on Gaming Licensing, Parl Paper No 96 (2008) 21-27, 30, 69-70.

${ }^{15} \mathrm{I}$ have been reliably informed that a motion to suspend Mr Lenders for three weeks was considered by the former leadership but was not pursued by the current leadership.

${ }^{16}$ Victoria, Report on the Gambling and Lotteries Licence Review Panel to the Minister for Gaming in relation to the current Public Lottery Licensing Process, Parl Paper No 49 (2007); Victoria, Minutes of the Proceedings, Legislative Council, 11 October 2007, 204.
} 
Committee's final report had been tabled ${ }^{17}$ for over six months without further action as this article went to press - the point of law about the powers of the Legislative Council is of course unaffected and an important point. It remains open for future exploration when later demands for documents are made.

Before considering the Attorney-General's propositions of law, ${ }^{18}$ I should point out finally that the government in power during these events was, with the principal and obviously important exception of the Premier himself, the same government which in 2003 had paved the way for these events. This is because, on obtaining a majority in both Houses of Parliament after the elections of November 2002, the government had Parliament pass legislation reforming the Legislative Council by introducing a system of proportional representation. This system made it much more difficult for any government, including that government then in power, to obtain a majority in that House ever again. ${ }^{19}$ No praise is too high for this principled step, which has greatly increased the usefulness of the Parliament of Victoria to the body politic.

Of course, clashes between the two Houses of Parliament are made much more likely by these reforms. The drafting suggests that most attention was devoted to the inevitable clashes over legislation when the proposed reform of the Legislative Council was being debated in the government party rooms in early 2003, but since there had been a well-publicised case in which documents had been required from a government by the Legislative Council of New South Wales ${ }^{20}$ this possibility too must surely have been the subject of some consideration. While the government's actions in 2007 are less than might have been hoped for, the fact remains that the initial decision in 2003 to create an effective upper House capable of causing serious problems to governments of any stripe, including the government that continued in power after the reforms took effect, cannot be the subject of anything but praise.

I turn now to a consideration of the legal merit of the objections urged on behalf of the government to the Council's order.

\footnotetext{
${ }^{17}$ Victoria, Minutes of the Proceedings, Legislative Council, 8 May 2008, 367.

${ }^{18}$ This article does not deal with the procedural and remedial aspects of possible litigation to determine the extent of the Council's powers nor with questions of justiciability. There is a useful recent contribution on this point: Enid Campbell and Matthew Groves, 'Parliamentary Privilege and the Courts: Questions of Justiciability' (2007) 7 Oxford University Commonwealth Law Journal 175.

${ }^{19}$ Constitution (Parliamentary Reform) Act 2003 (Vic), Part 2 Division 2 and s 40.

${ }^{20}$ Egan $v$ Willis (1998) 195 CLR 424; Egan $v$ Chadwick (1999) 46 NSWLR 563. A further recent case along the same lines from Western Australia is Aboriginal Legal Service (Western Australia) v Western Australia (1993) 9 WAR 297.
} 


\section{ADDRESS OR ORDER FOR THE CROWN'S DOCUMENTS?}

\section{A Law}

The Attorney-General's first argument is that, in cases in which privilege would exist before a court, government documents can only be sought by Houses of Parliament using the medium of a non-binding address requesting their production which does not have the formal status or effect of an order. He says that the Houses have no legal power to require the production of privileged documents by order, and that this is demonstrated by the fact that the House of Commons, on which each Victorian House's powers are based, follows the same rule.

Were this correct, the Houses could not even know which of the two procedures - address or order - to adopt in cases in which a privilege is not obviously available for a document and if there is no advance indication by the executive of whether privilege is claimed over any particular document. Such uncertainty would certainly be odd and constitute a procedural dilemma, with which no House of Parliament has ever actually grappled.

The lack of precedent for dealing with such a dilemma is no coincidence, because we shall see shortly that this alleged rule of law does not exist but merely rests upon a misunderstanding of a passage in an old edition of the leading English textbook on the practice as well as a misunderstanding of the powers of Parliament. There is even recent Australian case law strongly suggesting that the Attorney-General's objections have no substance. In Egan $v$ Chadwick $^{21}$ it was held that the Legislative Council of New South Wales was able to order the production of documents from Ministers who were its members regardless of litigation privileges, with one exception to which I shall shortly come. No restriction to addresses rather than orders was even considered by the Court there. Although the documents sought in that case were not within the category of documents for which the Standing Orders of the Legislative Council of New South Wales required the adoption of an address as a matter of parliamentary practice, ${ }^{22}$ a rule of law requiring an address to be moved - if one existed - would obviously have prevailed over the failure of Standing Orders to require that to occur and would have required the attention of the Court; but the Court does not waste a single syllable on the topic. The explanation for this is simple: there is no such rule of law, and the practice of addressing for copies of documents rather than

\footnotetext{
${ }^{21}$ (1999) 46 NSWLR 563.

${ }^{22}$ See below $n 55$.
} 
ordering their production does not reflect a legal restriction on the powers of each House of Parliament but is a parliamentary practice only, which any House is free to use or not to use as it wishes.

An argument a fortiori is available in Victoria, because in New South Wales there is no provision conferring the powers of the House of Commons on either House of the State Parliament. The Legislative Council of New South Wales was accordingly compelled to rely upon the common law doctrine that a legislative chamber without such a special conferral has only the powers justifiable by the doctrine of reasonable necessity. It cannot be that the Victorian express provision for the conferral of the Commons' powers, which go beyond reasonable necessity in a number of areas, has the effect of reducing the powers of the Victorian Legislative Council. ${ }^{23}$

This reasoning is confirmed by the legal history which forms the background to the Victorian provision. The whole point of introducing the archetype of section 19 of the Constitution Act 1975 (Vic) ${ }^{24}$ was to overcome the then recent decision of the Privy Council in Kielley $v$ Carson $^{25}$ which had exposed the fact that colonial legislatures had substantially lesser powers than the Commons unless there were a statutory conferral of those powers on a colonial legislature. ${ }^{26}$ As New South Wales has never adopted a provision conferring the Commons' powers upon its Houses, it has chosen to remain with Kielley powers. But the original version of section 19 provided the statutory provision for Victoria that was needed to ensure that its Parliament's powers were not as limited as the rule in Kielley would otherwise have required.

There is a further reason for concluding that the powers conferred on the Victorian Houses were known and intended to be very ample from the start. The original draft of the Victorian Constitution of 1855 was going to confer the Commons' powers directly on each House of Parliament, ${ }^{27}$ as indeed section 19 of the present Constitution Act 1975 does, but this plan was abandoned at the last minute in 1854 on the motion of the Collector of Customs, H C E Childers, because the proposal was 'judged too wide. It was accordingly agreed that they [the powers] should be the subject of special

\footnotetext{
${ }^{23}$ Egan v Willis (1998) 195 CLR 424, 462-515.

${ }^{24}$ Section 1 of Act No. 1 (1857) (Vic).

${ }^{25}$ (1842) 4 Moo PCC 63; 13 ER 225.

${ }^{26}$ See Victoria, Parliamentary Debates, Legislative Assembly, 15 January 1857, 276, where the future Stawell CJ states that, without what was to become s 1 of Act No 1, the Houses would possess 'no privilege whatsoever'.

${ }^{27}$ Victoria, Parliamentary Papers, vol III (1853-54) 630, cl 33.
} 
definition, with the proviso that they should not exceed those of the House of Commons. ${ }^{28}$ This proposal was duly adopted in section 35 of that original Constitution of 1855 and the question was thus left open. When what was to become section 1 of Act No 1 (1857) (Vic) was being drafted less than three years later, the project of special definition had been abandoned, perhaps because it had been realised that it would be too time-consuming. The earlier proposal of simply declaring that each House had the same powers as the Commons was adopted by section 1 of Act No 1 at the level of subconstitutional law. The great width of the powers being conferred by this means had not been forgotten in the intervening three years. Childers had been elected to the Legislative Assembly sitting in 1857, was still Commissioner of Trade and Customs when the Act was going through, and had yet to embark upon his second life which saw him fill a variety of prominent political offices in the United Kingdom.

In Egan the Court of Appeal for New South Wales made, as I mentioned earlier, an exception for Cabinet documents, which, the Court held by majority only, cannot be the subject of an order for production by the Legislative Council of that State as this might be inconsistent with the principle of Cabinet solidarity. Given the difference in the legal basis of the powers of the New South Wales and the Victorian Houses of Parliament which has just been referred to, this does not by any means necessarily apply to the Houses of the Victorian Parliament, whose powers extend far beyond mere reasonable necessity. A more readily comparable jurisdiction is Canada, where each House of the Parliament has essentially the same legal powers to send for documents as the Victorian Houses: the Canadian Houses have the same privileges as the UK House of Commons had on 1 July $1867 .{ }^{29}$ In Canada a recent leading work on the subject states:

By convention, a parliamentary committee will respect Crown privilege when invoked, at least in relation to matters of national and public security.

In the final analysis, witnesses [including those required to produce documents] must rely on the collective common sense of the members of the committee and their good graces. ${ }^{30}$

In relation to the federal Australian Parliament the same view - that each House of Parliament's powers are unrestricted, but that it wisely refrains from exercising them in certain cases including those involving Cabinet

\footnotetext{
${ }^{28}$ The Argus (Melbourne), 22 February 1854, 3-4 (italics in original).

${ }^{29}$ Parliament of Canada Act, RSC 1985, c P-1, s 4(a).

${ }^{30}$ Joseph Maingot, Parliamentary Privilege in Canada (2 ${ }^{\text {nd }}$ ed, 1997) 191 (emphasis added).
} 
documents - was taken in 1972 by one present and one future AttorneyGeneral. Both of them - Greenwood A-G QC and Ellicott S-G QC- had a good grasp of their obligations to provide legally correct advice. ${ }^{31}$

Although it is not my principal concern here, I am not entirely convinced that Egan correctly states the law of New South Wales on the strict legal powers of each House of Parliament either. Placing the deliberations of Cabinet beyond the reach of Parliament as a matter of strict law seems to me to invert the constitutional hierarchy. In Victoria (as indeed in New South Wales) the Cabinet is merely a collection of persons maintained in office by the will of Parliament. Furthermore, its legal profile is very low. The word 'Cabinet' itself does not even appear in the Victorian Constitution Act $1975 .^{32}$ There is old Australian authority, not cited in Egan, for the proposition that the formal constitutional law does not even recognise its existence. In $R v$ Davenport $^{33}$ an objection was taken to a question about the doings of Cabinet on two grounds: that Cabinet had no formal existence, and that its deliberations were secret. Mr Justice Lutwyche, a former Attorney-General for New South Wales and member of its Legislative Council, whose judicial record was hardly that of mindless conservatism or supine deference to the executive, ${ }^{34}$ upheld the objection on the first ground alone.

It need hardly be said that the formal constitutional law does recognise, on the other hand, the existence of Parliament and the powers of each of its Houses. In Victoria those powers extend generally to ordering the production of documents. It would seem odd if the strict legal powers of the highest organ of the state were restricted in relation to a body that officially does not even exist and has no constitutional powers. ${ }^{35}$ (Shortly I shall refer to possible conventional limitations.)

\footnotetext{
${ }^{31}$ Australia, Parliamentary Paper no 168/1972, 30.

${ }^{32}$ For a survey of Cabinet's appearances in the law, see Greg Taylor, Constitution of Victoria (2006) 144-7.

${ }^{33}$ (1874) 4 QSCR 99. For the final outcome of the case, see Davenport $v$ R (1877) 3 App Cas 115.

${ }^{34}$ See Peter Howell's biography of his Honour in the Australian Dictionary of Biography, vol 5.

35 I am of course aware that the practical need for Cabinet's deliberations to remain confidential is recognised today outside the field of constitutional law. It has been recognised in cases such as Commonwealth v Northern Land Council (1993) 176 CLR 604, 615 in which a recognised privilege in the law of evidence was applied with especial sensitivity to Cabinet. Given that the law of evidence attempts to draw a distinction between executive documents that are important enough to be protected by privilege and those that are not, there can of course be no objection to considering the real-world importance of Cabinet documents in this context. But if executive privilege does not affect the powers of each House of Parliament, this case is of no utility in determining the strictly legal extent of those powers.
} 
Nowadays of course we are not quite as shy about admitting the existence of Cabinet in case law and even from time to time on the statute book, but in strict law it, unlike the Houses of Parliament, remains still a very shadowy body with next to no formal powers. We should recall also that the Victorian Houses' powers to require the production of documents go back to 1855 when Lutwyche J's approach was the prevailing one, and recent cases in the High Court of Australia suggest an increasing role for the prevailing understanding of constitutional and statutory arrangements at the time of their enactment. $^{36}$

The Ministers who comprise the de facto body known as Cabinet are stated, at least in the Victorian Constitution, ${ }^{37}$ to be 'responsible' to Parliament and not merely to the lower House, as the judgments in Egan $^{38}$ explicitly recognise. It may be that in a system such as that of the United States, in which the executive is formally separate from and co-ordinate with the legislature, there is a good reason for executive privilege of the type suggested. But how could this be so in a polity in which Parliament is, as a matter of constitutional theory and practice, ${ }^{39}$ not separate from but in charge of and standing above the executive (including Cabinet) as the chief organ of the state, and (I am consciously avoiding the over-used word 'sovereign') is the body with powers undefined because not subjected to any internally sourced limitations beyond the law itself, of which Parliament is also master? For these reasons, therefore, I am not inclined to agree that the exception recognised in New South Wales, even if it exists there (a question on which there is no authority of the High Court of Australia), could apply in Victoria.

It might be objected that Parliament consists of two Houses and that the government, while clearly accountable to the Legislative Council as stated in Egan, is equally clearly not responsible to it in the full sense in which it is to the Legislative Assembly, as only the latter House can pass an effective motion of no confidence or block the budget. ${ }^{40}$ It must be recalled, however, that under section 19 of the Victorian Constitution Act 1975 the two Houses' powers to require the production of documents are, whatever else they may

\footnotetext{
${ }^{36}$ The most obvious recent example is Roach $v$ Electoral Commissioner (Commonwealth) (2007) 233 CLR 162; another is Cole v Whitfield (1988) 165 CLR 360.

${ }^{37}$ Constitution Act 1975 (Vic) s 50(2).

${ }^{38}$ Egan $v$ Willis (1998) 195 CLR 424, 453, 476, 502.

${ }^{39}$ Despite all party dominance, this is exemplified still by (for example) the fact that a majority of votes combined with a minority of seats in the lower House constitutes a loss at a general election. I am also of course aware that Parliament as a whole is the sovereign, not either House alone. On this I refer to what has recently been written by Campbell and Groves, above n $18,186$.

${ }^{40}$ Constitution Act 1975 (Vic) ss 8A, 65.
} 
be, equal. Thus, the Attorney-General's position necessarily implies that the Legislative Assembly also cannot order the Cabinet, which it controls and maintains in office and which is required to give an account to it, to produce documents. This would be grossly inconsistent with the constitutional hierarchy.

It may be thought that either House of Parliament may abuse its power to send for the documents of Cabinet. ${ }^{41}$ The obvious retort is that the government might abuse any power it had to conceal documents on the excuse that they are those of Cabinet. Certainly experience with the Egan rule in New South Wales suggests that it is vulnerable to abuse through the executive's propensity to claim Cabinet privilege too readily. ${ }^{42}$ A little more reflection will lead us to appreciate, further, that there are many rules of constitutional law that might be worked in such a way as to damage the polity severely, but practices have developed to prevent this from occurring.

It is well known that claims to executive privilege are not accepted without demur by the Courts nowadays, but that they will inspect documents, including Cabinet documents, privately if the need arises upon the making of such a claim. ${ }^{43}$ There is no reason why either House of Parliament should accept such a claim without demur either, and in Sessional Order 21 the Legislative Council of Victoria has created a process for the determination of such claims modelled on that adopted in New South Wales for other claims to privilege. ${ }^{44}$ With the assistance of that process, Parliament is just as capable as the Courts - if not more so - of carrying out the function of balancing when documents alleged to be covered by public interest immunity are tendered before them. ${ }^{45}$

\footnotetext{
${ }^{41}$ Gerard Carney, 'Egan $v$ Willis and Egan v Chadwick: The Triumph of Responsible Government' in George Winterton (ed), State Constitutional Landmarks (2006) 328.

${ }^{42}$ Beverly Duffy, 'Orders for Papers and Cabinet Confidentiality post-Egan v Chadwick' (2006) 21:2 Australasian Parliamentary Review 93.

${ }^{43}$ See for example John Dyson Heydon, Cross on Evidence $\left(7^{\text {th }}\right.$ ed, 2004), 893-895. Even in 1860 there was a dissenting judicial voice in favour of this course of action: Beatson $v$ Skene (1860) $5 \mathrm{H} \& \mathrm{~N} 838,854 ; 157$ ER 1415, 1422. The dissenting view was adopted in Hennessy $v$ Wright (1888) LR 21 QBD 509, 515.

${ }^{44}$ Victoria, Minutes of the Proceedings, Legislative Council, 14 March 2007, 51-2. A minor difference is pointed out by Anne Twomey, Executive Accountability to the Australian Senate and the New South Wales Legislative Council (Legal Studies Research Paper no 07/70, Sydney Law School 2007), 3, fn 7. The article contains an excellent critical assessment of the workings of the process adopted in New South Wales.

${ }^{45}$ Cf Egan v Chadwick (1999) 46 NSWLR 563, 574, 594.
} 
In assessing the merits of fears of possible abuse of power by a House of Parliament, the convention that the Cabinet documents of one government are not shown to its successors should be recalled. This convention works well enough and is uniformly observed by all politicians in the medium-term interest of all concerned, despite their theoretical power to order the public servants who enforce the convention to produce the documents. ${ }^{46}$ Thus there is no reason to suspect that, where Cabinet documents are truly involved, the upper House of Parliament, although also made up of politicians, cannot be trusted to observe a similar degree of discretion in the interests not only of today's, but also of tomorrow's government (which is today's opposition). The same would apply to any lower House in which the government may be in a minority and which may order the production of documents.

As one of the most distinguished politicians-turned-judges of what is now Ontario put it in 1830 when a similar argument was urged before him as Chief Justice of the Court of King's Bench of Upper Canada, with the intent of having the legislature's privileges legally restricted:

Arguments were very ingeniously raised upon the possible abuses that might follow the recognition of the power exercised in this case by the Assembly, and some of them certainly were formidable in appearance at least; but every objection of this nature would equally be against the House of Commons. [...] The true point of view in which to regard the question is that these powers are required by the House in order to enable them to promote the welfare of their constituents; we are bound to suppose that they will use them with discretion and for good ends; and if we had the power we should have no right to withhold them on the assumption that they desire to pervert the objects of their constitution. ${ }^{47}$

\section{B Practice}

I turn now to consider the parliamentary practice of seeking documents by addresses rather than formal orders. Practice rather than law is the source of the idea of addressing for rather than formally ordering the production of documents, and it will be seen that this practice too does not have the meaning which the Hon the Attorney-General for Victoria attributes to it.

In 1855 , the practice of the House of Commons was as follows:

\footnotetext{
${ }^{46}$ Greg Taylor, Constitution of Victoria, (2006) 147-98.

${ }^{47}$ McNab v Bidwell and Baldwin (1830) Draper UCR 144, 155 (KB) (Draper CJ).
} 
The ordinary accounts relating to trade, finance and general or local matters are ordered directly, and are returned in obedience to the order of the House whence it was issued; but returns of matters connected with the exercise of Royal prerogative are obtained by means of addresses to the Crown.

The application of the principle is not always clear: but as a general rule, it may be stated that all public departments connected with the collection or management of the Revenue, or which are under the control of the Treasury, may be reached by a direct order from either House of Parliament; but that public officers and departments, subject to Her Majesty's secretaries of state, are to receive their orders from the Crown.

Thus returns from the Commissioners of Customs and Inland Revenue, the Post-office, the Board of Trade and the Treasury are obtained by order. [...] Addresses are presented for treaties with foreign powers, for despatches to and from the governors of colonies, and for returns connected with the civil government, and the administration of justice. ${ }^{48}$

(I suspect that the above passage, having been discovered by the AttorneyGeneral or an adviser, is the true source of his ingenious argument that a House of Parliament has no power to order some government documents, as distinct from asking for them by means of an address to the Crown.)

The modern English practice which, given the absence of any amendments in this respect to the Houses' powers since 1855, may be taken as good evidence of the legal situation in $1855,{ }^{49}$ is expressed more succinctly in the current edition of Erskine May:

A return from the Privy Council or from departments headed by a Secretary of State is called for by means of a humble Address to the Sovereign; a return from elsewhere, such as a department not headed by a Secretary of State, is sought directly by means of an order of the House. ${ }^{50}$

\footnotetext{
${ }^{48}$ Thomas Erskine May, A Practical Treatise on the Law, Privileges, Proceedings and Usage of Parliament ( $3^{\text {rd }}$ ed, 1855) 411-412.

49 There is an analogy here with our acceptance of rulings on the common law by English Courts as still having some authority in Australia. The difference is that the Australian common law has been severed from direct access (and subordination) to the source by the abolition of appeals to Her Majesty in Council, whereas s 19 of the Constitution Act 1975 (Vic) expressly preserves the link in the area under consideration here.

${ }^{50}$ William McKay, Erskine May's Treatise on the Law, Privileges, Proceedings and Usage of Parliament (23 ${ }^{\text {rd }}$ ed, 2004) 263.
} 
A less far-reaching division was adopted in nineteenth-century Canada, ${ }^{51}$ at a time when the governmental institutions of that country, generally speaking, bent over backwards to follow English procedures in all their refinements. Bourinot's Parliamentary Procedure and Practice ${ }^{52}$ records that until 1876 only addresses were ever used for the production of papers,

but since that time the more regular practice of the English Houses has been followed. It is now the usage to move for addresses only with respect to matters affecting Imperial interests, the Royal prerogative, or the Governor[General] in Council. On the other hand, it is the constitutional right of either House to ask for such information as it can directly obtain by its own order from any department or officer of the government. ${ }^{53}$

The breadth of those concluding words needs no emphasis. The important point to note for future reference is that the secretaries of state and their departments have disappeared from the list of addressees. The modern Canadian manual is to the same effect, updated to substitute for the reference to Imperial interests a reference to inter-governmental correspondence and to include judicial matters. ${ }^{54}$ In New South Wales also, both Houses include the administration of justice (as well as the Governor) in the list of subjects about which addresses must be sent - out of sensitivity, no doubt, to the need to respect the separation of powers. ${ }^{55}$

In New Zealand, the situation is similar. The Legislature Act 1908 (NZ) fixes 1865 as the date on which the Commons' powers were transmitted to the one remaining House of the New Zealand Parliament, so knowledge of what happens across the Tasman is also highly useful in Victoria. The standard text there outlines the House's power to acquire documents by order and states only that ' $[\mathrm{w}] \mathrm{h}$.re the document that the House desires to have produced is in the hands of the Governor-General, its production is sought by means of an address'. ${ }^{56}$ Standing Orders in the Senate ${ }^{57}$ and in South

\footnotetext{
${ }^{51}$ See above $\mathrm{n} 29$.

52 Sir John Bourinot, Parliamentary Procedure and Practice with a Review of the Origin, Growth and Operation of Parliamentary Institutions in the Dominion of Canada $\left(2^{\text {nd }}\right.$ ed, 1892).

${ }^{53}$ Ibid 332-334, where examples are given of the distinction. See also Derek Lee, The Power of Parliamentary Houses to Send for Persons, Papers \& Records: A Sourcebook on the Law and Precedent of Parliamentary Subpoena Powers for Canadian and Other Houses (1999) $127-8$.

${ }^{54}$ Robert Marleau and Camille Montpetit (eds), House of Commons Procedure and Practice (2000) 399.

55 Victoria, Legislative Council, Standing Order 53(c); Victoria, Legislative Assembly, Standing Order 268(4).

${ }^{56}$ David McGee, Parliamentary Practice in New Zealand (3 ${ }^{\text {rd }}$ ed, 2005) 531.
} 
Australia $^{58}$ also require addresses only for Vice-Regal documents, and appear to assume that all others, as stated by Bourinot, are available by order.

In the Standing Orders of the Legislative Assembly of Victoria, the very House in which Hulls A-G sits, Standing Order 171 recognises an apparently unlimited power to order the production of documents. This is qualified only by Standing Order 172, which has remained virtually unchanged, except for its numbering, since the first standing orders of $1856^{59}$, and which runs (with added emphasis):

When the royal prerogative is concerned in any document required by the House, an address will be presented to the Governor requesting that the document is tabled in the House.

It is possible that the concept of the Royal prerogative is being used here in a broad, loose nineteenth-century sense, on which more will be said shortly. However, whatever the exact connotation of the phrase is intended to be, there is certainly nothing here, as there is nothing in any of the other standing orders to similar effect, about executive, legal professional or any other form of litigation privilege.

No mention is made of addresses in the Standing Orders of the Legislative Council of Victoria, which provide an apparently unlimited power to order the production of documents. ${ }^{60}$ That omission would not, of course, prevent the Council from addressing if it wished to, since the law compels no-one to use their formal powers before they have first asked for cooperation. However, there is no indication that there is any practice limiting the House's powers to merely asking for any type of document by address.

With the exception of England, in which a more elaborate procedure apparently continues to flourish, provisions in Standing Orders for addresses as a means of seeking documents are rarely used today, even in jurisdictions in which addresses continue to exist. Indeed, the Australian Senate, despite

\footnotetext{
${ }^{57}$ New Zealand, Senate, Standing Order 165.

${ }^{58}$ South Australia, Legislative Council, Standing Order 449; South Australia, House of Assembly, Standing Orders 199, 200.

${ }^{59}$ See Victoria, Legislative Assembly, Standing Order CCLXVI in the Assembly's Votes and Proceedings, 15 July $1857,366$.

${ }^{60}$ It appears that there was nothing on the topic in the Council's first Standing Orders: Victoria, Legislative Council, Votes and Proceedings, 30 July 1857, 186ff. This too would not have prevented the making of orders or addresses to the extent permitted by law, but merely meant that the any motion for an order or address would have needed to specify the machinery for compliance such as is now set out in Standing Order 9.02.
} 
its often vigorous pursuit of government documents and consequent claims by the government for various exemptions, has not presented an address for some decades. ${ }^{61}$ The House of Representatives never did so at all before its Standing Order providing for addresses to be used was repealed in a recently completed revision because it was 'out of date'. ${ }^{62}$ Now that the Vice-Regal office is entirely powerless, as it has been since roughly the end of Empire, there is little occasion in Australian jurisdictions for asking for its documents and thus little need for the procedure of addressing it, for which some standing orders still provide.

Indeed, some of the standing orders just referred to expressly mention addresses to the Governor for copies of despatches, as if Governors still regularly received despatches from the Secretary of State for the Colonies. In the Legislative Assembly of Victoria (as no doubt elsewhere) the words 'royal prerogative' in what is now Standing Order 172 were apparently and quite reasonably taken to include Imperial interests, and addresses were indeed sometimes moved, rather than orders made, for copies of despatches. ${ }^{63}$ This made sense, as a House of Parliament would not have wished to run into trouble with the Colonial Office by demanding something which was an Imperial secret. But of course this complication no longer exists.

In the colonial period also, both orders and addresses were made in Victoria for government documents. For example, an address for information about the Royal Mint in 1880 is followed shortly by an order for statistics about land tax, both of these being presented by a Minister ${ }^{64}$ and suggesting that the distinction between addresses relating to matters under the Royal prerogative (as the coinage then was) and orders for all other government documents may once have been rigorously observed. But of course few Royal prerogative powers remain nowadays either; almost all powers have become statutory, and if this parliamentary practice is retained it will not often be used. The case which prompted this note clearly did not involve the Vice-Regal office, the British Empire, the judicial system or any Royal prerogative - in short, it involved nothing which prompts some but not all Houses of Parliament to make addresses rather than orders their practice.

\footnotetext{
${ }^{61}$ JR Odgers and Harry Evans (ed), Australian Senate Practice (11 ${ }^{\text {th }}$ ed, 2004) 442.

${ }^{62}$ House of Representatives Standing Committee on Procedure, Parliament of Australia, Discussion Paper: Proposed Revised Standing Orders (2002), A-58; see also Ian Harris (ed.), House of Representatives Practice ( $4^{\text {th }} \mathrm{ed}$, 2001) 575. Accordingly the current (fifth) edition of the manual just referred to does not mention the topic of addresses for documents.

${ }^{63}$ For example, Victoria, Votes and Proceedings, Legislative Assembly, 19 May 1880, 22.

${ }^{64}$ Victoria, Votes and Proceedings, Legislative Assembly, 7 September 1880, 29; 22 September 1880, 52; 25 November 1880, 119.
} 
I have not attempted to trace the unfolding of Victorian parliamentary practice in this regard in full because the case I am meeting is that the practice of addressing is required as a matter of law. The Standing Orders of various jurisdictions, Erskine May and the other procedural manuals detail the practice rather than the law of Parliament. And while the sources referred to describe the practice of addressing, at no point is it stated in any of them that any House's legal powers are restricted to the submission of a humble address to the Crown. Nor indeed is it suggested that the Crown would ordinarily go so far as to ignore the stated wishes of a House of Parliament for access to a document.

My brief review of British and Australian standing orders and parliamentary practices indicates that, if the view of the Attorney-General for Victoria were correct, which it is not, clearly a lot of other legislative chambers with legally identical powers to those of the Victorian Legislative Council (or even, in the case of New South Wales, with lesser powers) would now be mistaken about the extent of their powers. Their procedures would provide for addresses in far too few of the very numerous cases in which they could not legally issue orders. Among the legislative chambers thus mistaken would be the one in which the Attorney-General himself sits.

Furthermore, the review just presented shows that the practice of addressing had and, where it survives, continues to have nothing to do with litigation privileges, and the Attorney-General's view is confused on this point. Obviously, privilege as known to the law of evidence might not be available in a court in relation to some documents that even the Commons, under its fairly broad version of the practice, might request by an address. Conversely, the Commons might order documents from the Treasury which reveal defence-related secrets such as the price of components of armaments and would thus be privileged in litigation. Pace the Attorney-General for Victoria, despite the obvious variations in practice among the jurisdictions here reviewed, there is no fit in any jurisdiction between the class of privileged documents under the law of evidence and the classes of documents which under these various parliamentary practices cannot be required by order but rather must be sought by asking politely in an address. It would, in fact, be quite surprising if there were any fit between this obviously rather ancient practice of addressing and the law of executive privilege, which was in its infancy in $1855 .^{65}$

\footnotetext{
${ }^{65}$ One of the earliest cases is that referred to above, $\mathrm{n} 43$, but there were a few others before 1855, such as Smith v East India (1841) 1 Ph 50; 41 ER 550.
} 
What has been said so far is more than sufficient to dispose of the AttorneyGeneral's case on this point, but curiosity is also aroused about the true reason for the distinction made in the practice of the Parliament of the United Kingdom between documents held by the Treasury that can be ordered by Parliament and those held by a Secretary of State that are merely requested by means of a humble address. In order to satisfy this curiosity, it is necessary to look back a long way into the mists of constitutional history, and when we do this we discover that the practice of addressing even in the United Kingdom may not be legally required.

The practice goes back to the time when the Secretary of State was nothing less than what the title of the office taken literally would suggest, namely a personal secretary to the King. The Secretaries of State in the United Kingdom are no longer personal servants of the monarch, but they were until early modern times, ${ }^{66}$ and it is from this that the polite practice of seeking documents only by address has survived.

It is understandable that some legitimate reluctance might be felt at requiring the production of documents from the King's personal household. While the occasional monarch might take such requirements amiss for reasons which cannot be endorsed in today's world, the monarch's secretary's papers might contain, for example, the monarch's personal correspondence with his family as well as his official correspondence as monarch. The same closeness to the personal affairs of the monarch was never enjoyed by the Treasury; indeed, the central and ultimately successful claim first of Parliament and then of the Commons alone to be in control of all public money pointed distinctly in the opposite direction, ${ }^{67}$ and must have induced the Commons to refuse to adopt even symbolic reminiscences of any contrary earlier state of the law which it was content to retain, in relation to the secretaries of state, in the form of the practice of addressing.

In Australia we do not have the office of Secretary of State at all and therefore the rule requiring addresses only to Secretaries of State would not be applicable here even if it reflected a rule delineating the strict powers of the Commons (of which more shortly). The only office in modern Australia that could be said to be the equivalent of that office in its mediaeval function (and thus perhaps entitled to the benefit of the rationale for the practice of

\footnotetext{
${ }^{66}$ Florence Higham (in Principal Secretary of State (1923) 10-12) and Sir William Holdsworth (in A History of English Law (1981) vol X, 460, 462, 494) place this development in the first half of the seventeenth century.

${ }^{67}$ Florence Higham, Principal Secretary of State, (1923) 330.
} 
seeking documents by address only in order to protect the personal privacy of the head of state) is the office of Official Secretary to the Governor. Also entitled to the same degree of consideration is, of course, the Vice-Regal representative personally. This explains in large part why, in various jurisdictions, the practice has been adopted of moving only an address and doing so solely in relation to the Vice-Regal office. This practice is a correct adaptation of the pre-modern practice to modern realities. When the Governor regularly received despatches from the Colonial Office, it was also a correct adaptation of the ancient English practice to colonial realities to send addresses for such documents to the Vice-Regal office, because not all of them could be shared with the colonial Parliament. Those jurisdictions in which standing orders require addresses to be made for documents relating to the royal prerogative, such as the Legislative Assembly of Victoria, may have introduced that practice partly because the royal prerogative was deemed to include such Imperial matters, and partly because of a sense that the prerogative powers were the 'natural' powers of the Crown which should not be lightly interfered with by Parliament. A comparable reservation was made even in the Engineers' Case ${ }^{68}$ but now that prerogative powers have virtually disappeared in favour of statutory powers, and the survivors are accidental relics only, this feeling has entirely dissipated.

If documents were ever sought nowadays from the Vice-Regal office, it could first be argued that the Houses had no power to compel, as distinct from addressing for, the production of Vice-Regal documents, as the Governor is a co-equal constituent element of Parliament ${ }^{69}$ and may also be immune from the compulsory giving of evidence at common law. ${ }^{70}$ It may also be that considerations of politeness and respect for privacy would lead our local Parliaments to address rather than order anyway, regardless of the view taken

\footnotetext{
${ }^{68}$ Amalgamated Society of Engineers v Adelaide Steamship Co. Ltd (1920) 28 CLR 129, 1434.

${ }^{69}$ In Victoria at least: Constitution Act 1975 (Vic) s 15; Australia Act 1986 (Imp \& Cth) s 7 (1), (2). There is a law or custom that one House of Parliament does not require the members of the other to give evidence: Greg Taylor, Constitution of Victoria, (2006) 276-7; see further for a Canadian exception and commentary Derek Lee, The Power of Parliamentary Houses to Send for Persons, Papers \& Records: A Sourcebook on the Law and Precedent of Parliamentary Subpoena Powers for Canadian and Other Houses, (1999), 166-7. As long as there are Ministers in the Legislative Council, however, this principle will not constitute an obstacle to orders for Cabinet documents by that House.

${ }^{70}$ For recent proceedings discussing this, see O'Sullivan v Central Sydney Area Health Service (No 2) [2005] NSWADT 136, [18]-[20]. There is also useful information in Derek Lee, The Power of Parliamentary Houses to Send for Persons, Papers \& Records: A Sourcebook on the Law and Precedent of Parliamentary Subpoena Powers for Canadian and Other Houses, (1999)1-2.
} 
on those points as a matter of law. This would have the consequence that non-production for good reasons, such as the preservation of the Governor's legitimate interest in personal privacy, would not constitute a contempt, although no doubt the Official Secretary would be anxious to provide such information as might be proper in the circumstances. However, there is not the slightest reason why the English practice in relation to the Secretaries of State, based on mediaeval realities and an office which has never existed in this country, should be adopted in relation to what section 50(2) of the Constitution Act 1975 (Vic) calls the 'responsible Ministers of the Crown'. These persons are responsible to Parliament and in no sense the personal servants of the Crown, as the Secretaries of State once were. As we have seen, the standing orders of various jurisdictions recognise this legal position by not in fact providing, as a matter of practice, for addresses in such cases.

There is a further point. Even if the English practice were applicable to our State Ministers, which it is not, it may be merely politeness and a respect for tradition that have induced the Commons to perpetuate the ancient English practice, rather than a lack of strict legal power to order the production of documents from the Secretaries of State. The question of the Commons' strict legal power to require, as distinct from request, documents from the Secretaries of State appears never to have been resolved in the United Kingdom. The question last appears to have been dealt with when Charles I complained in 1626 to the Commons, in the middle of the period in which the office of Secretary of State was being transformed from that of a personal royal servant to that of minister of state,

That your Committees have prefumed to examine the Letters of Secretaries of State, nay, his own, and fent a general Warrant to his Signet-Office, and commanded his Officers, not only to produce and hew the Records, but their Books and private Notes, which they made for his Majefties service. This his Majefty holds as unfufferable, as it was in former times unufual. ${ }^{71}$

The Committee for Religion had been searching, among other things, for royal correspondence relating to the pardoning of certain 'popish priests'. ${ }^{72}$ The Commons' answer to the King's complaint was that

touching Publick Records, we have not forborn, as often as our bufineffes have required, to make fearch into them, wherein we have done nothing

\footnotetext{
${ }^{71}$ John Rushworth, Historical Collections of Private Passages of State (1659) vol I, 227.

${ }^{72}$ William Bidwell and Maija Jansson (eds), Proceedings in Parliament 1626 - Volume II: House of Commons (1992) 205.
} 
unwarranted by the Laws of your Realm, and the conftant ufage of Parliaments. ${ }^{73}$

It is understandable, given the end to which Parliament led Charles I and given Parliament's own excesses in the seventeenth century, that the question of the Commons' strict legal powers has since been discreetly allowed to rest unresolved. ${ }^{74}$ Thus the practice of requiring documents by address only may well rest on politeness combined with the desire to avoid unnecessary arguments, and not to be a matter of the strict legal powers of the Commons.

In summary then, the practice of addressing for some government documents does not reflect anything to do with executive or any other privilege. Even if it is a strict rule of law in England, the practice is not a rule of law in Australia because the office to which it is applied in England does not exist here. The Attorney-General's claim in this respect fails on every point and the Legislative Council was right to believe that it had the power to make an order in relation to the government.

It is for politicians to negotiate and decide about how the Legislative Council's legal powers can be used without damage to the legitimate interests of the government, just as they do in this field in New South Wales and in numerous other fields in which the rules of the constitution could be, but are not, operated in a way that harms the body politic.

\section{CAlling for Documents from Private Parties}

Another extraordinary claim (also made by some of the private parties from which the Victorian Select Committee required documents) ${ }^{75}$ is that a House of Parliament cannot require documents to be produced by private parties unless they are discharging special functions or using public money. The obvious objection to this alleged principle in relation to the Victorian Commission for Gambling Regulation is that it is not a private body. ${ }^{76}$ The

\footnotetext{
${ }^{73}$ Ibid 249. This exchange, along with other documents relating to it, is most conveniently found in William Bidwell and Maija Jansson (eds), Proceedings in Parliament 1626 - Volume II: House of Commons (1992) 205, 348-9, 357, 393, 420, 433.

${ }^{74}$ At least, I can find no reference in the standard manuals and textbooks or in more detailed works of reference in which this episode is recounted to any later consideration of the question or final resolution of the dispute. See for example Florence Higham, Principal Secretary of State (1923) 189.

${ }^{75}$ See the Victoria, First Interim Report: Select Committee of the Legislative Council on Gaming Licensing, Parl Paper No 30 (2007) 9, 12.

${ }^{76}$ See above, nn 1 and 7.
} 
Commission may hold and be required to produce documents originating with private bodies, but these bodies are clearly in receipt of a special, and very lucrative, privilege if they conduct state-authorised gaming pursuant to licences. ${ }^{77}$ However, it is not necessary to debate the precise content and application of the supposed principle in order to dispose of this objection, because the principle itself does not exist.

The doubts expressed in $\operatorname{Egan}^{78}$ about whether the Legislative Council of New South Wales can require documents from persons who are not members of that House ${ }^{79}$ are simply inapplicable to its Victorian equivalent, as the latter has and the former has not the powers of the House of Commons conferred upon it by statute. In relation to Victoria, the question is therefore whether the principle contended for by Hulls A-G restricted the powers of the House of Commons in 1855.

Josef Redlich, in a 1908 work to which the Clerk of the House of Commons also contributed, expressly states that the memoranda of any subject of the state may be examined by the Commons. ${ }^{80}$ No statement to the contrary may be found in the third (1855) edition of Erskine May. By the following fourth edition of 1859, however, the following passage appears, which is almost certainly the source for the supposed principle put forward by Hulls A-G. Documents, it is said in the 1859 Erskine May,

may be obtained from all public offices, and from corporations, bodies or officers constituted for public purposes, by Acts of Parliament or otherwise;

\footnotetext{
${ }^{77} \mathrm{Cf}$ the list, rather broader than that proffered by Hulls A-G, of the sorts of non-government persons in whose doings Parliament may well choose to take an interest that is provided by Enid Campbell, Parliamentary Privilege (2003) 162. It is also worth noting that the call for registrations of interest in the grant of a public lottery licence expressly stated that Parliament may require the production of associated documents (Victorian Government Gazette, no S113, 17 June 2005, 10). On the position taken here, this statement has no direct legal effect on Parliament's capacity to have the documents produced. Nevertheless, it underlines the point made in the text. If there were a privilege available as a legal answer to the Legislative Council's demands, submission of papers to the government on these terms might be argued to be a waiver of it; and if the documents were to be produced but a claim for confidentiality maintained, this notice might well be used as a means of arguing that there is no great injustice in disclosing some or all of their contents.

${ }^{78}$ Most of their Honours simply reserved their position on the law of New South Wales, but McHugh J was more definite in his doubts. See Egan v Willis (1998) 195 CLR 424, 456, 458, $468,472,504,511$.

${ }^{79}$ I except here members of the other House. See above $n 69$.

${ }^{80}$ Josef Redlich (trans Steinthal), The Procedure of the House of Commons: A Study of its History and Present Form (1908), vol II, 39.
} 
but not from private associations, such as Lloyd's for example, nor from individuals not exercising public functions. ${ }^{81}$

What is the source for this suddenly created qualification? After the word 'example' in the passage quoted there is a footnote referring to the eleventh volume of Hansard's Debates, at column 271. Unfortunately there are several volumes of Hansard's Debates with that number, because several series were published, and none of them supports the statement quoted. Indeed, when the twelfth edition of Erskine May was published in 1917 the statement about Lloyd's was retained but the footnote was removed, perhaps because on checking it was found to be misleading. ${ }^{82}$

The reference to Lloyd's makes one suspect that perhaps the reference is supposed to be to some other debate on its affairs in which the question arose whether documents should be called for from Lloyd's, but without searching every volume of the debates of the House of Commons to 1859 it is hard to see how any such reference could be discovered. Given that the statement appeared in Erskine May between the editions of 1855 and 1859 it might be thought that the source for the statement could be found in the few volumes of the debates for that period, but I have not been able to discover it there either. There is, however, a volume 11 of Cobbett's Parliamentary History of England, as printed by T C Hansard, ${ }^{83}$ in which we find Horatio (later Lord) Walpole arguing at column 272, without any reference however to Lloyd's,

that no parliamentary enquiry ought ever to be set on foot, but when there is an absolute and apparent necessity for so doing; and therefore, I shall next observe, that there never can be such a necessity, but when there appears to have been a flagrant error in some part of the conduct of our public affairs. A national misfortune is no just cause for a parliamentary enquiry, unless there be ground to believe, that it was owing to the crime, the neglect or the weakness of those who were concerned in advising or conducting our public affairs.

This speech was given on 29 November 1739, just after the War of Jenkins's Ear had begun - on the surface as a result of a naval incident involving private shipping, although not Lloyd's - and the occasion for the speech was a motion for an address for the presentation of papers connected with that war. Perhaps this speech then is the source of the statement in the 1859

\footnotetext{
${ }^{81}$ Thomas Erskine May, A Practical Treatise on the Law, Privileges, Proceedings and Usage of Parliament ( $3^{\text {rd }}$ ed, 1855) 492.

${ }^{82}$ Thomas Erskine May (with $\mathrm{T}$ Lonsdale Webster), A Treatise on the Law, Privileges, Proceedings and Usage of Parliament $\left(12^{\text {th }}\right.$ ed, 1917) 563.

${ }^{83}$ William Cobbett and T C Hansard, Cobbett's Parliamentary History of England (1812).
} 
edition of Erskine May. If so, it need hardly be stated that Walpole's speech indicates that the question before the House on 29 November 1739 related to the desirable use of Parliament's resources, not its legal powers. This indeed was expressly stated by Horatio Walpole's brother, the Prime Minister (Sir Robert Walpole), later in the debate: 'no man, I believe... will ever deny our right to enquire. But there may be such a thing as an improper or imprudent enquiry. ${ }^{84}$ If my detective work has yielded the correct solution, the statement in Erskine May turns out to be advice, no doubt well intentioned but given in a very politically charged context, on the wise use of Parliament's powers, and certainly not a statement about their legal extent.

Sources closer to our own time and place confirm this. In House of Representatives Practice, the reference in a standing order to the seeking of documents only from Ministers of the Crown is also stated to reflect merely a 'general rule', ${ }^{85}$ not a legal limitation of the House's powers to require the production of documents from anyone. And when the Legislative Council of the Parliament of Western Australia required the production of documents by the Aboriginal Legal Service of Western Australia Inc, a body incorporated under the Associations Incorporation Act 1987 (WA), and the order was challenged before the Full Court of the Supreme Court of the State, no-one suggested for a moment that the Aboriginal Legal Service's private-law status posed any obstacle to that course, or required the Council to show that it was in receipt of public funding or performing a special function. Rather, the Court expressly confirmed the power of the House to order the production of documents from a private body. Admittedly there were some aspects of the West Australian legislation that have no equivalents in Victoria and made this conclusion even easier to reach, but it was not suggested that the legislation reversed any rule to the contrary rather than just providing machinery for the exercise of a pre-existing power over private parties' documents. ${ }^{86}$ Finally, in looking for any past cases in which the Victorian Houses of Parliament had ordered the production of documents involving private companies I found one in the very first volume of the Legislative Assembly's papers that I pulled off the shelves - an order of the Legislative Assembly, immediately complied with, for production of the agreement between the Melbourne and

\footnotetext{
${ }^{84}$ Ibid col 293.

${ }^{85}$ Ian Harris (ed), House of Representatives Practice $\left(5^{\text {th }}\right.$ ed 2005) 591.

${ }^{86}$ Aboriginal Legal Service (Western Australia) v Western Australia (1993) 9 WAR 297, 314. I do not burden this note with a discussion of the sources of the Western Australian Houses' powers, which appear sufficiently from the judgments.
} 
Hobson's Bay United Railway Company and the colonial government for the purchase of the former's undertaking. ${ }^{87}$

Further weight is given to the idea that it is a House of Parliament's choice whether to order the production of private documents in the exercise of its legal powers by the fact that parliamentary committees clearly do not observe any rule to the contrary. They have from time to time ordered private parties to produce documents. Committees' powers are of course derived via delegation from the House and could not legally exceed those of the parent body. Therefore committees must be exercising powers that also belong to the House. That they, unlike the whole House, should seek private parties' documents more often also makes sense as a practical matter. The task of a committee is quite specific: it is to enquire thoroughly into a narrowly defined field. Unlike the whole House, it has a mandate of enquiry that, while relatively narrow in area, may go quite deep. This is perhaps why it has come to pass that committees are recorded as having sent for private papers more often than the whole House has done, but for the reason just given, the practice of committees must reflect the legal powers of the House.

It is certainly true that the Parliament of the United Kingdom has very occasionally refused to order privately held documents. Most notably, in July 1884 it cancelled an address to Her Majesty - not an order - for a copy of a book on the ground that it 'related to a private matter, over which the House had no jurisdiction, and involved a question of copyright' ${ }^{88}$ But this was simply self-restraint in the interests of not infringing the copyright. The book was available for purchase, so the information was hardly denied to the House in the end; and if the matter was a private one it may also be presumed that an address to Her Majesty was not the right way of going about acquiring the document.

There is certainly no general practice in the United Kingdom of not seeking private parties' documents. A report from the Commons' Select Committee on Procedure in 1978 lists three occasions from 1732 to 1835 in which private persons who refused to produce documents, most of which were those of private bodies, were taken into custody for contempt. The most recent of

\footnotetext{
87 Victoria, Votes and Proceedings, Legislative Assembly, 16 July 1878, 11; Victoria, Parliamentary Debates, Legislative Council, 16 July 1878, 77; Victoria, Parliamentary Papers, vol I (1878) 11 and 563.

${ }^{88}$ House of Commons Journals, 1 July 1884, 331; 3 July 1884, 336.
} 
those cases was in 1835 and involved the non-production of a letter-book, ${ }^{89}$ and there is another from 1732 involving the secretary of a private company. The following sentence may also be found in the Committee's 1978 report:

There is no limitation on a committee's power to order the production of papers by private bodies or individuals, so long as they are relevant to its work, although attempts to do so in respect of multinational companies may be complicated by considerations of international law. ${ }^{90}$

Recalling that the House of Commons' legal powers have not been increased in this regard since they were conferred upon the Victorian Legislative Council on 21 July 1855 , it is instructive to note that committees of the House of Commons have on three occasions in the twentieth century required documents from private persons. ${ }^{91}$ The present edition of Erskine May notes simply that ' $[\mathrm{t}]$ here is no restriction on the power of committees to require the production of papers by private bodies or individuals, provided that such papers are relevant to the committee's work as defined by its order of reference'. ${ }^{92}$ The statement in the 1859 edition has been rightly abandoned as unsupportable either in law or by practice. The modern Canadian manual makes the same point about the unrestricted powers of the House as a whole and thus a fortiori about its committees. ${ }^{93}$ The same stance is taken also in the equivalent publication from New Zealand, referring expressly to committees. ${ }^{94}$

The most recent of the occasions in the United Kingdom on which private parties' documents were ordered to be produced was in 1998, when a body styling itself the United Grand Lodge of England was required by order of the Home Affairs Committee to produce papers identifying persons adhering

\footnotetext{
${ }^{89}$ Also referred to in Derek Lee, The Power of Parliamentary Houses to Send for Persons, Papers \& Records: A Sourcebook on the Law and Precedent of Parliamentary Subpoena Powers for Canadian and Other Houses (1999) 49-50.

${ }^{90}$ First Report from the Select Committee on Procedure, House of Commons Paper 588I/1977-78, lxxxix, 28.

${ }^{91}$ Two of these, one apparently involving a request that was pressed by means of an order for attendance rather than strictly for the production of documents, are noted in Leopold, 'The Power of the House of Commons to Question Private Individuals' [1992] Public Law 541, 541-3, n 5. Note that the absence of an elective upper House in the United Kingdom renders inapplicable to this country some of the further remarks made there about the difficulty of requiring documents from ministers and conventions.

${ }^{92}$ William McKay, Erskine May's Treatise on the Law, Privileges, Proceedings and Usage of Parliament (23 ${ }^{\text {rd }}$ ed, 2004) 757.

${ }^{93}$ Robert Marleau and Camille Montpetit (eds), House of Commons Procedure and Practice (2000) 106, 865.

${ }_{94}^{94}$ David McGee, Parliamentary Practice in New Zealand (3 ${ }^{\text {rd }}$ ed, 2005) 428.
} 
to freemasonry during its inquiry into the influence of freemasonry on English life. The order was complied with. ${ }^{95}$ It is beyond all doubt that committees of a House of the Victorian Parliament have the power to require the production of documents from private persons, and that the whole House does too.

\section{STATUTORY DISPLACEMENT OF THE HOUSE'S POWERS?}

Finally, Hulls A-G relies on the provisions of section 10.31.1 (1) of the Gambling Regulation Act 2003 (Vic), which provides that information must not be disclosed by a series of persons including the Commission to 'a court', and section 10.1.34(1) of the same statute, which requires third parties to which protected information is disclosed not to disclose it 'to someone else'. Section 10.1.29(1) defines 'court' to include 'any tribunal, authority or person having power to require the production of documents or the answering of questions'.

There is little that needs to be added to the opinion of Bret Walker SC provided to the Select Committee ${ }^{96}$ to show that these provisions are simply inapplicable to the Houses of Parliament. Clearly neither Parliament nor either of its Houses is a 'tribunal, authority or person' ${ }^{97}$ It is hardly arguable that a House of Parliament is a 'person' or 'tribunal'. ${ }^{98}$ It might be said that a House of Parliament has, in one sense, authority to require documents, but the abstract concept of authority to do an act (a sense in which the word is used in unrelated provisions of the statute in question here $)^{99}$ is not what is connoted by the collocation 'person, authority or tribunal'. The basic principle that a statutory word or phrase noscitur a sociis (is known by its friends), which most law students still learn in first year, indicates that the

\footnotetext{
${ }^{95}$ The order is printed in House of Commons Paper 573/1997-98, and the full report it is also available at $<$ http://www.parliament.the-stationeryoffice.co.uk/pa/cm199899/cmselect/cmhaff/467/46703.htm> (visited 15 April 2006). See [13], n 25 of the report just cited.

${ }^{96}$ Reproduced in Victoria, Second Interim Report: Select Committee of the Legislative Council on Gaming Licensing, Parl Paper No 48 (2007).

${ }^{97}$ Pace Anne Twomey, Constitution of New South Wales (2004) 520-9. It is not every body having the power to send for documents which is included in this definition - only those that are tribunals, authorities or persons.

${ }^{98}$ For an example of a statute which treats Parliament as not a tribunal, see Charter of Human Rights and Responsibilities (2006) (Vic) s 4(1)(i), (j). 'Person' is defined in s 3(1)(b) of the Act, and (if this definition is still applicable) also in s 38 of the Interpretation of Legislation Act 1984 (Vic), in a manner that also clearly does not include Parliament.

${ }^{99}$ Such as the heading to Part 4, Division 1.
} 


\section{DEAKIN LAW REVIEW \\ VOLUME 13 No 2}

reference here is to something like a tribunal or a body of persons with powers of its own, such as a statutory authority. This impression is reinforced by the distributive sense of 'any' which precedes that collocation and is apt to refer not to authority as an abstract concept but to the possibility of a plurality of entities - any one or more authorities. That also is the sense in which the word is used in surrounding provisions of the statute, such as section 10.1.2.

It would clearly be a stretch of language, not to say demeaning, to refer to a House of Parliament as a mere 'authority' in this sense, or as 'someone else'. Furthermore, the presumption is against such stretching of language in order to include a House of Parliament in such contexts. As Walker SC points out, Parliament is not to be taken to have removed its own powers (including the powers which each House holds individually and can exercise without the consent of the other, and indeed even including personal immunities of its members) unless legislation states so expressly or by necessary intendment. ${ }^{100}$ Although Walker SC gives no authority for the principle, it is supported by sufficient authority from both English and recent Australian cases. ${ }^{101}$ The principle merely reinforces what we should expect to be the case from just reading the Victorian statute, namely that its secrecy provisions apply to the bodies that the statute mentions, and do not apply to those that it does not mention, such as Parliament: expressio unius est exclusio alterius.

The principle prohibiting an unduly rapid conclusion that Parliament has removed the powers of its own constituent parts was, it is true, rather less well received recently in Canada (House of Commons) $v$ Vaid. ${ }^{102}$ But the point was not considered in much detail in that case and the Court's statements were clearly obiter dicta: the Court held that the privilege contended for in that case would not have been applicable on the facts of that case even if there had been no statute applicable.

Furthermore, the statute held applicable in Vaid applied to the employment relationship between the Speaker of the Canadian House of Commons and

\footnotetext{
${ }^{100}$ Walker, above n 96, 9 .

${ }^{101}$ Newcastle (Duke) v Morris (1870) LR 4 HL 661, 668; Aboriginal Legal Service (Western Australia) v Western Australia (1993) 9 WAR 297 304; Criminal Justice Commission (Queensland) v Parliamentary Criminal Justice Commissioner (Queensland) [2002] 2 Qd R 8, 23.

${ }^{102}$ [2005] 1 SCR 667, [80]. It should also be noted that the South Australian Industrial Court managed a similar feat to that of the Canadian Supreme Court with greater economy of reasoning in Bear v South Australia (1981) 48 SAIR (Pt 2) 604, 619-623, as did the Federal Court of Canada in Pankiw v Canada [2007] 4 FCR 578. In the latter case, an application for leave to appeal to the Supreme Court of Canada (no 32 501) was dismissed on 26 June 2008.
} 
his chauffeur and was the Canadian Human Rights Act. The importance of that statute and the contrastingly quotidian nature of the relationship to which it applied suffice to explain the statute's application even to Parliamentary relationships of employment and might justify, even if the Court had held a privilege to be involved, some relaxation of the usual cautious approach to the discernment of an implied statutory abrogation. In contrast, the recent case in Victoria involved a special power of each House of Parliament to call for documents, a power shared with very few other bodies.

Furthermore, Victoria's Charter of Human Rights and Responsibilities is drafted so as to be inapplicable to this case. If it were otherwise, there would be a serious question whether or not a requirement to produce documents might infringe the Victorian Charter's protection of privacy $^{103}$ for example (it may well do), and, if so, whether or not the limitation can be demonstrably justified in a free and democratic society (s 7(2)). However, under the law of Victoria those corporations from which Parliament has demanded documents do not have any human rights - section 6(1) of the Charter insouciantly resolves this fundamental question for us Victorians. Even more importantly, Parliament's non-legislative powers, such as that in issue here, do not fall under the Charter. This is because of the general exclusion of Parliament and proceedings in Parliament from the Charter's field of operation under section 4(1)(i) ${ }^{104}$ and Parliament's subjection to the Charter only in carefully defined ways during the legislative process (s $6(2)(a))$. Thus, unlike the position in Vaid, the statutory context in Victoria points distinctly away from, rather than towards, a laxer approach to the discernment of a statutory restriction of the powers of each House of Parliament.

The principle that Parliament should not be taken to have disposed of its own, or its constituent elements', powers without an express statement to that effect is in fact also a very wholesome one, at least as beneficial to the polity as human rights statutes, and that is so for reasons that the Supreme Court of Canada did not consider in its brief and sometimes over-simple consideration of the question in Vaid. What was said in that case must be seen through the prism of the facts of that case, and should not be taken as establishing a new

\footnotetext{
${ }^{103}$ Section 13(a).

104 The special inclusion in $\mathrm{s} 4(1)(\mathrm{g})$ of members of a Select Committee when acting in an administrative capacity (an example of this might be a committee's role as de jure or de facto employers; cf Kimmitt v R (1896) 5 Ex CR 130; Bear v South Australia (1981) 48 SAIR (Pt 2) 604, 615-618; or a committee as a party to or acting under a contract as in $R v$ MacLean (1881) 8 Can SCR 210, 224-5, 246-7) places beyond doubt what would hardly be questioned anyway, namely that in this statute proceedings in Parliament otherwise include proceedings in a Committee (unless otherwise stated, as in s $4(1)(\mathrm{g})$ ).
} 
general principle or cancelling the old one except perhaps in the field of law in question in that case.

There are several reasons why the old principle is to be preferred in most situations. First, Parliament can, if it does so desire, easily reduce its or its Houses' own powers by simply adding a few extra words to the Bill in question. In the case at hand it would have been very easy to add the Houses of Parliament expressly to 'tribunal, authority or person'. Secondly, the presence of express words in a statute alerting each House of Parliament to the impending diminution in its important powers will ensure debate on the topic in a way that a mere implication would not. Finally, and most importantly, the non-legislative powers of the Houses of Parliament at issue in Victoria are of great importance to the polity. They are considerably more important than Parliament's general powers to employ people, which were at issue in Vaid, because they are a means of ensuring the accountability of the executive to Parliament. Powers to inquire are also important to the Parliament qua legislature itself, because an inquiry may reveal the need for legislation.

Therefore there is every reason to uphold the principle against facilely assuming that Parliament has taken away its Houses' own powers in cases in which (unlike Vaid) it does actually have them before the enactment of a statute.

Finally it should be noticed, given that section 10.31.1(1) of the Gambling Regulation Act 2003 (Vic) provides that the information in question cannot be the subject of provision to a court, that, while the court-like powers to compel the attendance of a witness, call for documents, punish for contempt and so on of the United Kingdom's Parliament are generally taken to have originated by reason of the status of the English Parliament as a high court, so that Parliament's and the courts' powers share one origin in this respect, Parliament and the courts are, in Australia, clearly separate institutions. Furthermore, the common origin of the two sets of powers did not prevent later separation and divergence: if the Commons had had the courts' powers to administer an oath in 1855, there would be no need for section 19A of the Constitution Act 1975 (Vic). ${ }^{105}$ Thus, there is of course no warrant for reading 'court' in section 10.31.1(1) as including the Houses of Parliament for historical reasons.

${ }^{105}$ Lord Mansfield may be found denying that the Commons is a Court of record as early as 1774: Jones $v$ Randall (1774) 98 ER 944, 944. 


\section{CONCLUSION}

No doubt it was inevitable that the principled enthusiasm of the government in power in 2003 for an independent upper House would wane if, as happened at the elections of 2006, it lost its majority there and found itself on the receiving end of some robust independence in a real case. That does not, however, diminish the praise that is due to that government for creating such an institution, as it must have known that it was likely to be making a shortterm rod for its own back as well as conferring a lasting benefit upon the Victorian polity, a benefit that will continue to exist for decades, perhaps centuries, to come.

Research indicates that the objections of law urged by Hulls A-G, based, it seems, on a superficial and tendentious reading of the 1859 edition of Erskine May and the Gambling Regulation Act 2003 (Vic), cannot be supported. Either the principles of law contended for by the Attorney-General do not exist at all, or they are mere niceties of practice or guidelines for the exercise by a House of Parliament of its undoubted legal powers. The upper House in New South Wales has so far shown itself able to exercise an appropriate degree of restraint in dealing with confidential information, and there is no reason to suspect that its Victorian equivalent, while armed with slightly wider powers, would exercise them any less well.

It is hard to escape the suspicion that the Attorney-General has merely constructed or endorsed a politically convenient argument based on certain passages from the 1859 edition of Erskine May and has failed to look beyond what was of current utility in the political arena. Without putting too fine a point on it, if this assessment is correct then it must be said that the AttorneyGeneral's obligation, as first law officer to the Crown and to Parliament, should have entailed a greater degree of disinterestedness in dealing with the legal aspects of this case. That would still have left more than enough room for argument about the desirable use of the House's legal powers and it is on that field that parliamentarians should concentrate their attention.

If the Legislative Council is serious about enforcing the principle of the government's accountability to it - and through it to the whole people of Victoria - in the sense which Egan has established and which is now practised to some extent in New South Wales, it will need to begin imposing significant sanctions for non-compliance in cases such as these. ${ }^{106}$ The opposition parties cannot escape criticism either as a result of the case dealt

${ }^{106}$ On the sanction actually imposed, see above, text accompanying nn 11-13. 
48 Deakin LaW ReVIEW

VOLUME 13 No 2

with here if they failed to ensure that such sanctions were imposed because of a political judgment that a concentration on other topics was more fruitful or because they were concerned that serious sanctions might also be used against them when they are next in government and facing a similar inconvenient demand for information. It is most important that the constitutional authority of each House, given to it in the interests of good government, should not be flouted. 